Reprod. Nufr. Dévelop., 1980, 20 (4 B), 1217-1235.

\title{
The adaptation of digestive enzymes to the diet : Its physiological significance
}

\author{
par T. CORRING
}

Laboratoire de Physiologie de la Nutrition, I.N.R.A. 78350 jouy en josas, France.

Summary. Digestive enzymes adapt to the diet when substrate intake is altered. An analysis of experimental works shows that this process includes many enzymes. The intestinal step of digestion is the most important in the enzyme breakdown of dietary components.

In the first part of this paper, I have pooled the data on the adaptive potency of pancreatic and intestinal enzymes. When protein, carbohydrate and lipid digestions are considered successively, it is clear that the enzymes involved adapt to any change in substrate intake. For instance, when the amount of starch intake increases, the specific activity of pancreatic amylase is stimulated. At the same time, augmenting the disaccharide level leads to an increase in specific disaccharidase activity, and the absorption rate of some simple hydrolytic products, such as fructose, increases. It thus appears that altering the amount of starch intake leads to a parallel change in the activity of all the enzymes involved in the sequential hydrolysis of the dietary carbohydrates.

The second part of the paper discusses the physiological significance of this adaptation in terms of utility to the animal. Two situations are considered in which (i) the nutritional requirements are supplied by food or (ii) they are not supplied either because of a dietary or an enzyme deficiency.

When the nutritional requirements, particularly that of protein, are met, adaptation is apparently not useful to the animal. Nevertheless, the role of this adaptation on the hydrolysis rate of different substrates can be supposed. When nutritional requirements are not met, some data show that enzyme adaptation may be advantageous to the animal. If dietary restriction is not too severe and thus the biosynthesis of all the enzymes markedly decreases, then digestive secretions would export considerable nitrogenous material into the gastrointestinal lumen ; this material could be a substrate compensating for the essential components lacking in the diet.

Any enzyme deficiency leading to substrate decrease is similar to a dietary deficiency. Many experimental studies have shown that in pancreatic deficiency the adaptive potency of the organism is responsible for establishing digestive compensation.

\section{Introduction.}

The concept of digestive enzyme adaptation to the diet was first advanced in 1897 by Pavlov, and has been studied since by many researchers. The etymological origin of «to adapt to » is found in the Latin "aptare ad » which means to adjust to with the aim of..., the verb «to adapt to » and the noun «adaptation » implying the notion of finality. Increased pancreatic proteolytic activity, for instance, would intervene to insure the hydrolysis of a greater amount of protein substrate, and that would carry the idea of a definitive adjustment. Does this idea of finality, in relation to enzyme 
adaptation to the diet, include the notion of utility? In 1951, Cuenot wrote : « As its etymology implies, the word 'adaptation' means an adjustment, an accommodation of the organism to the internal and external conditions of existence, an adjustment such that the living machine can function, endure and reproduce; this exclusively vital term implies the idea of arrangement more than of utility or necessity. »

The first part of the present paper analyzes some experimental data demonstrating the existence and the extent of digestive enzyme adaptation to the diet ; the second part discusses the physiological significance of this adaptation in terms of utility to the animal.

\section{Digestive enzyme adaptation to the diet.}

The hydrolysis of dietary components occurs mainly in the intestinal part of the digestive tract under the action of pancreatic and intestinal enzymes. This paper will be limiled to the discussion of the adaptation of these two large enzyme groups to the diet. However, it should be noted that salivary amylase activity varies with the type and quantity of carbohydrate intake (Zubstov and Podorozhnaya, 1979), and that gastric pepsins are sensitive to any dietary changes; the activity of these enzymes increases in the rat when dietary protein intake augments (Snook and Meyer, 1964) or varies in the dog with the type of protein (Storozuk, 1968).

In order to conserve the specific character of the enzyme-substrate relation, the different types of pancreatic and intestinal enzymes intervening successively in dietary protein, carbohydrate and lipid hydrolyses will be discussed.

\section{Protein digestion.}

When they arrive in the duodenal lumen, the non-degraded dietary proteins and the polypeptides from gastric digestion are hydrolyzed simultaneously or consecutively by pancreatic proteolytic enzymes and intestinal peptidases.

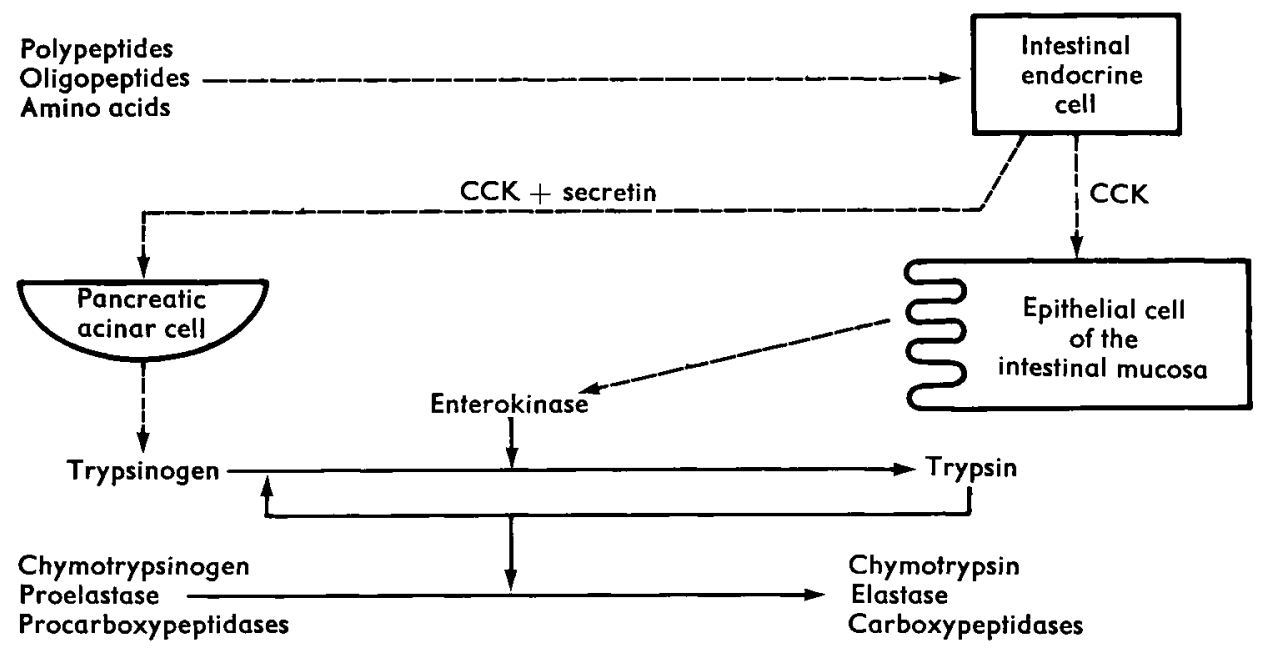

FIG. 1. - Secretion and activation of pancreatic enzymes (Freeman and Kim, 1978). 
1. - Pancreatic digestion. - Pancreatic proteolytic enzymes are excreted into the intestinal lumen in an inactive form and are activated by enterokinase acting on trypsinogen (fig. 1).

Any alteration in the type or quantity of dietary proteins leads to an adjustment of specific and total enzyme activities in the pancreatic tissue and the pancreatic juice. This adjustment has been described in the rat by Grossman, Greengard and Ivy (1943), Desnuelle, Reboud and Ben Abdeljlil (1962) (table 1), Howard and Yudkin

TABLE 1

Specific enzyme activities in the pancreatic tissue of rats fed diets containing 20 and 70 p. 100 of casein

\begin{tabular}{|c|c|c|}
\hline & $\begin{array}{l}20 \text { p. } 100 \text { casein } \\
56 \text { p. } 100 \text { starch }\end{array}$ & $\begin{array}{l}70 \text { p. } 100 \text { casein } \\
20 \text { p. } 100 \text { starch }\end{array}$ \\
\hline $\begin{array}{l}\text { Amylase } \ldots \ldots \ldots \ldots \ldots \\
\text { Lipase } \ldots \ldots \ldots \ldots \ldots \\
\text { Chymotrypsinogen } \ldots \ldots \\
\text { Trypsinogen } \ldots \ldots \ldots \ldots\end{array}$ & $\begin{array}{r}1014 \pm 54 \\
296 \pm 20 \\
15.1 \pm 0.8 \\
3.2+0.2\end{array}$ & $\begin{array}{r}167 \pm 11 \\
117 \pm 9 \\
27 \pm 2.9 \\
3 \pm 0.4\end{array}$ \\
\hline
\end{tabular}

From Desnuelle, Reboud and Ben Abdeljlil (1962). Specific activities are shown in units/mg of total protein.

(1963), Snook and Meyer (1964). It has been confirmed in many other species such as the milk-fed calf (Gorill and Thomas, 1967), chicken (Imondi and Bird, 1967), dog (Behrman and Kare, 1969) and pig (Corring and Saucier, 1972) (fig. 2).

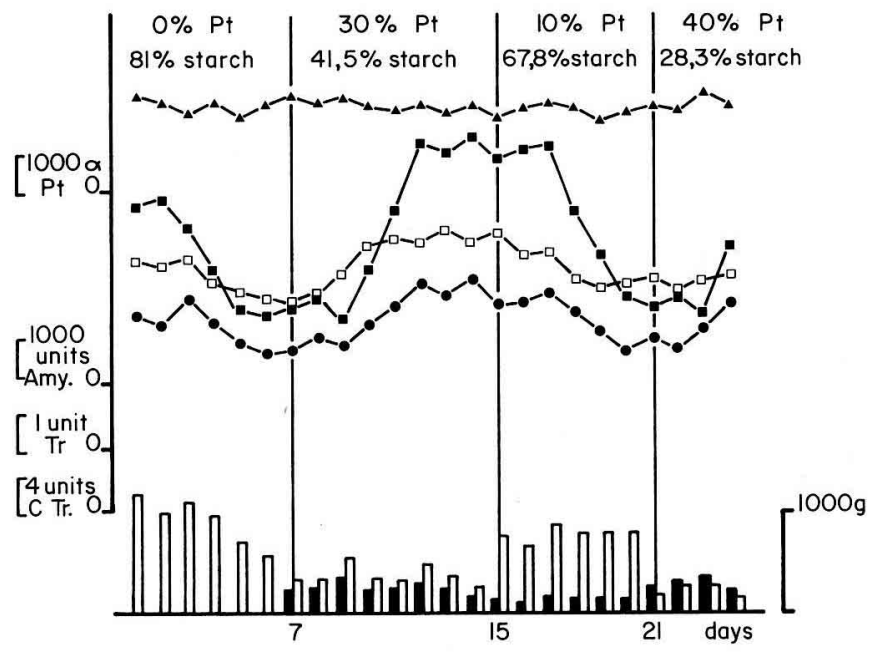

FIG. 2. - Exocrine pancreatic adaptation to dietary protein in the pig. Changes in specific enzyme activities and in total protein per $\mathrm{ml}$ of pancreatic juice. (Corring and Saucier, 1972).

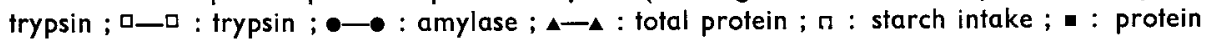
intake. 
Some studies seem to indicate that the digestive enzymes adapt principally to the amount of nitrogenous material ingested. This idea, which appears again in the present paper, was evidenced in the studies of Behrman and Kare (1969) in the dog, Hulan and Bird (1972) in the chicken and Corring and Saucier (1972) in the pig.

\section{2. - Intestinal digestion.}

The action of pancreatic proteolysis in the intestinal lumen releases amino acids and peptides. According to Gray and Cooper (1971) pancreatic intraluminal digestion releases 30 p. 100 of basic and neutral amino acids and 70 p. 100 of small peptides. The amino acids, as well as some peptides containing glycine or proline, are absorbed. Among the enzymes implicated in the hydrolysis and absorption of other peptides are the peptidases, located on the brush border of the intestinal mucosa, and the intracellular peptidases in the enterocyte cytoplasm. Several studies, using electrophoretic mobility, specific chain length, thermal stability and inhibitor effect, have shown that brush border enzymes are distinct from intracellular enzymes (Kim, Birtwhistle and Kim, 1972 ; Heizer, Kerley and Isselbacher, 1972). One of the first effects that dief has on the development of these enzymes is seen during fasting which causes brush border activities in the rat to decrease while the cytoplasmic activities increase (Kim ef al., 1973) ; this would imply that the former enzymes are adaptive. Nicholson, Mc Carthy and Kim (1974) showed that the brush border enzyme activities of rats eating the same amount of food increased with a protein-rich diet, while cytoplasmic enzyme activities did not vary (fig. 3 ). In the same study, the peptidase activities of the brush border declined when the high protein diet was replaced by a low-protein (10 p. 100 casein) - high carbohydrate one, while the activities of two disaccharidases, saccharase and maltase, augmented. According to the authors, this would show that the amount of protein intake had a stimulating effect on peptidase activities, and would thus be a specific adaptive process and not the translation of an overall enzyme response.

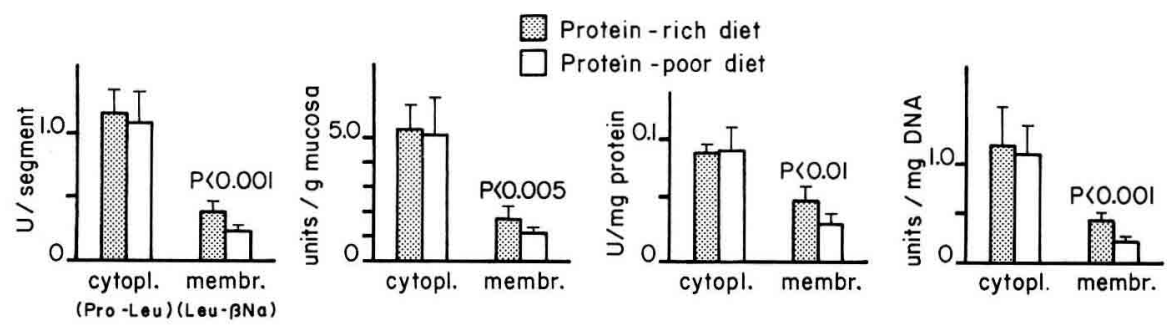

FIG. 3. - Peptidase activities of cytoplasmic and membrane fractions of the proximal small intestine of rafs fed protein-rich or poor diefs. The substrate for cytoplasmic enzyme activity is L-prolyl-L-leucine (Pro-Leu) ; that for membrane activity is L-leucyl- $\beta$-naphthylamide (Leu- $\beta-N a)$. Each histogram is the mean +1 SD of the data obtained on 6 rats (Nicholson, McCarthy and Kim, 1974).

It cannot be concluded only from a lack of intracellular enzyme response to a protein-rich or poor diet that the enzymes are not adaptive. According to Nicholson et al. (1974) the choice of the substrate is crucial in determining enzyme activity; these authors, using various specific substrates, showed that cytoplasmic peptidase 
activities adjust to the amount of protein intake (fig. 4). These results are very interesting since several dipeptides are absorbed in the enterocyte without previous hydrolysis (Adibi and Morse, 1971 ; Burston, Addison and Matthews, 1972) ; therefore, one of the putative functions of cytoplasmic peptidases may be the hydrolysis of absorbed peptides. However, many organs have cytoplasmic peptidases with the same electrophoretic profiles as the intestinal peptidases (Kim, Birtwhistle and Kim, 1972). This absence of organ specificity suggests that these intracellular enzymes may have a more general function in intracellular protein metabolism rather than a specific role in absorbed peptide digestion.

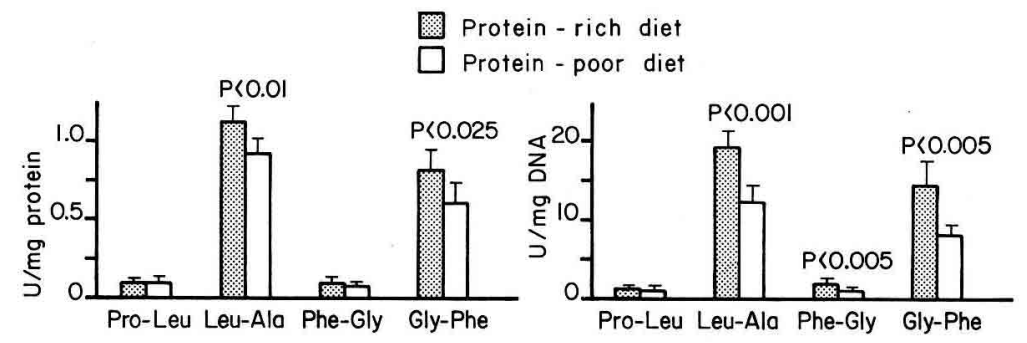

FIG. 4. - Peptidase activities in the cytoplasmic fractions of the proximal intestine of rats fed protein-rich or poor diefs. L-leucyl-L-alanine (Leu-Ala), L-phenylalalnylglycine (Phe-Gly) and glycyl-L-phenylalanine (Gly-Phe) are used as substrates. The results obtained with L-prolyl-L-leucine (Pro-Leu) are shown for comparison. Each histogram is the mean +1 SD of the data obtained on 6 rats (Nicholson, McCarthy and Kim, 1974).

Finally, varying the quantity of protein intake affects absorption mechanisms since Scharrer (1972) emphasized specific increases of amino acid transport in the rat (with equal intake) adapted to a diet containing 88 p. 100 casein as compared to a 13 p. 100 casein diet.

\section{Carbohydrate digestion.}

Starch is the principal dietary carbohydrate; if is hydrolyzed in the intestinal lumen by pancreatic $\alpha$-amylase into maltose, triose and $\alpha$-dextrins. The disaccharides are broken down into simple sugars by disaccharidases. In some species, intracellular glycolytic enzyme equipment insures the conversion of fructose into glucose.

\section{1. - Pancreatic digestion.}

Pancreatic amylase is very sensitive to any changes in the amount of starch intake. Desnuelle, Reboud and Ben Abdeljlil (1962) showed that specific amylase activity in the rat pancreatic tissue increased sixfold when animals, adapted to an 11 to 20 p. 100 starch diet, received food containing 56 to 75 p. 100 of starch (see table 1). This result was confirmed in the same species by Howard and Yudkin (1963) and Snook and Meyer (1964). Ben Abdeljlil and Desnuelle (1964) reported that variations in amylase activity in the pancreatic juice were altered with the diet. Pancreatic amylase adaptation was later described in other species such as dogs (Behrman and Kare, 1969), cattle and sheep (Clary et al., 1969). In the pig (Corring, 1975), increasing the daily 
starch intake from 160 to $600 \mathrm{~g}$ caused a mean $30 \mathrm{p} .100$ increase of specific amylase activity (fig. 5).

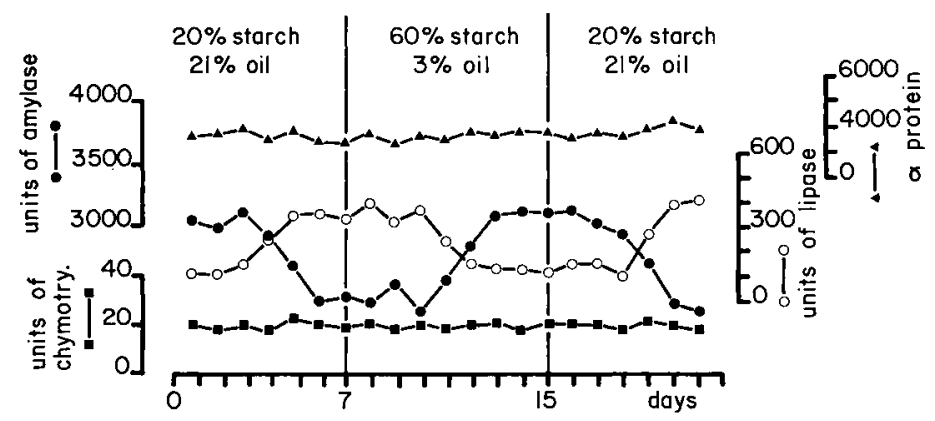

FIG. 5. - Exocrine pancreatic adaptation to dietary carbohydrate and lipid in the pig. Specific enzyme activities and total protein per $\mathrm{ml}$ of pancreatic juice (Corring, 1975).

\section{2. - Intestinal digestion.}

In human and animal nutrition, the main disaccharides are saccharose, maltose and lactose. Before being absorbed, they must be broken down into their monosaccharide components by disaccharidases (saccharase, maltase and lactase). These enzymes have been localized in the brush border of the intestinal mucosa (Miller and Crane, 1961 ; Eichholz, 1969) and several studies on humans and on rats have reported that some disaccharidase activities vary with the type and the amount of the carbohydrate substrate. The administration of saccharose and maltose thus increases specific saccharase and maltase activities (table 2) (Blair, Yakimats and Tuba, 1963 ;

\section{TABLE 2}

Effet of feeding saccharose, maltose and casein on saccharase and malfase activities in the rat small intestine

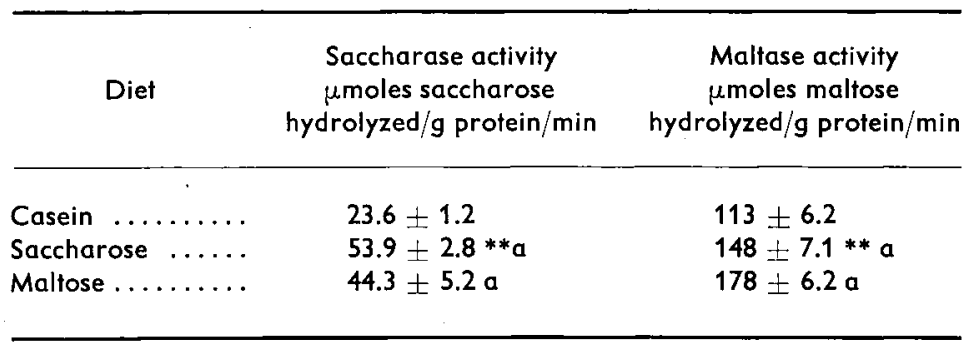

From Deren ef al. (1967). 17 rats per group.

$a: P<0.01$, comparison with casein diet.

** $: \mathrm{P}<0.05$, comparison with maltose diet.

Deren, Broitman and Zamcheck, 1967 ; Stifel et al., 1968). The results obtained on the chicken (Siddons, 1972 ; Blum, Gauthier and Guillaumin, 1979) are interesting : although the authors showed disaccharidase adaptation to dietary carbohydrate, 
that adaptation did not seem specific since all disaccharidase activity increased whatever type of carbohydrate was ingested (table 3).

\section{TABLE 3}

Specific disaccharidase activities (per $\mathrm{mg}$ protein) in the small intestine of the 25-day old chicken fed diefs confaining different carbohydrates

\begin{tabular}{|c|c|c|c|c|c|}
\hline & $\stackrel{A}{\text { Starch }}$ & $\begin{array}{c}\text { B } \\
\text { Glucose }\end{array}$ & $\underset{\text { Maltose }}{C}$ & $\begin{array}{c}\text { D } \\
\text { Saccharose }\end{array}$ & $\begin{array}{c}\text { Statistical } \\
\text { significance }\end{array}$ \\
\hline Maltase...$\ldots \ldots \ldots$ & 14.8 & 19.0 & 15.3 & 16.0 & ACDB \\
\hline Saccharase...$\ldots \ldots$ & 2.3 & 3.0 & 2.5 & 2.8 & $\overline{A C D B}$ \\
\hline
\end{tabular}

From Siddons, (1972).

10 chickens per group (A, B, D) and 8 in group $C$. bility.

Any two means not underscored by the same line differ significantly at the 5 p. 100 level of proba-

Fructose also causes saccharase activity to increase in man (Stifel et al., 1968). According to Rosensweig. Herman and Stifel (1971), fructose is the active component of the saccharose molecule and its intake may stimulate the activity of glycolytic enzymes for which fructose is the principal substrate. These enzymes are found in the soluble cytoplasmic fraction of the enterocyte. However, in man and rat, fructose intake increases fructokinase and Fru-1-P-aldolase (table 4). This is also true for glucose and galactose : the glucose stimulates specific hexokinase activity and the galactose that of galactokinase, galactose-1-phosphate uridyl transferase and uridine diphosphate galactose-6-epimerase (Stifel ef al., 1968 ; Rosensweig et al., 1968). The demonstration of the adaptive nature of intracellular glycolytic enzymes suggests that intestinal absorptive capacity is modified. Since fructokinase and Fru-1-P-aldolase augment with the fructose, the latter is probably more rapidly metabolized in the cell, thus increasing its absorption. Such an hypothesis is supported by the work of Deren, Broitman and Zamcheck (1967) and Vrana, Fabry and Kazdova (1977) who showed,

TABLE 4

Effect of diet on glycolytic enzyme activities in the rat jejunum

\begin{tabular}{lrrrrr}
\hline & Fructose & Saccharose & Glucose & Casein \\
\hline & & & & & \\
Fructokinase $\ldots \ldots \ldots \ldots \ldots \ldots$ & 41.5 & 27.3 & 15.4 & 7.3 \\
Fru-1-P-aldolase $\ldots \ldots \ldots \ldots \ldots$ & 69.1 & 45.1 & 16.4 & 9.2 \\
Hexokinase $\ldots \ldots \ldots \ldots \ldots \ldots$ & 1.7 & 2.9 & 4.2 & 1.3 \\
\hline
\end{tabular}

From Stifel ef al. (1968).

Activities are shown in nmoles of substrate metabolized per min per $\mathrm{mg}$ of protein. Carbohydrate diets : 17 p. 100 casein, 68 p. 100 carbohydrates ; Casein diet. : 85 p. 100 casein, 0. p. 100 carbohydrates. 
respectively, that rats with equal intake, fed a saccharose-rich diet, absorbed 4 times more fructose than those fed a casein-rich diet, and that a considerable amount of fructose was absorbed during a long-term diet containing that sugar. Vrana, Fabry and Kazdova (1977) excluded the possibility of an effect due to changes in the gastric emptying rate or intestinal motility. Fructose intake has specific effect on sugar absorption because these authors showed that glucose absorption was unchanged by the experimental diet.

Several authors have reported that intestinal lactase does not adapt to dietary carbohydrate changes in humans, rats or chickens (Deren, Broitman and Zamcheck, 1967 ; Rosensweig and Herman, 1969 ; Siddons and Coates, 1972) or to lactose or milk intake in man (Cuatrecasas, Lockwood and Caldwell, 1965 ; Knudsen ef al., 1968). On the contrary, other authors have shown that long-term lactose intake in the rat may increase lactase activity in some cases (Bolin, Pirola and Davis, 1969 ; Cain ef al., 1969) (table 5).

TABLE 5

Comparison of infestinal disaccharidase activities in rats fed 3 or 30 p. 100 lactose diets

\begin{tabular}{|c|c|c|c|c|c|c|}
\hline & \multicolumn{2}{|c|}{ Lactose } & \multicolumn{2}{|c|}{ Saccharase } & \multicolumn{2}{|c|}{ Maltase } \\
\hline & $\begin{array}{c}30 \text { p. } 100 \\
\text { lactose }(a)\end{array}$ & $\begin{array}{l}3 \text { p. } 100 \\
\text { lactose }(b)\end{array}$ & $\begin{array}{l}30 \text { p. } 100 \\
\text { lactose }\end{array}$ & $\begin{array}{l}3 \text { p. } 100 \\
\text { lactose }\end{array}$ & $\begin{array}{l}30 \text { p. } 100 \\
\text { lactose }\end{array}$ & $\begin{array}{l}3 \text { p. } 100 \\
\text { lactose }\end{array}$ \\
\hline $\begin{array}{l}\text { Jejunum ... } \\
\text { lleum .... }\end{array}$ & $\begin{array}{l}2.3 \pm 0.2 * * \\
0.5 \pm 0.04 \mathrm{NS}\end{array}$ & $\begin{array}{l}1.1 \pm 0.09 \\
0.3 \pm 0.03\end{array}$ & $\begin{array}{l}8.3 \pm 0.6 \mathrm{NS} \\
3.2 \pm 0.8 * *\end{array}$ & $\begin{array}{l}8.5 \\
0.7 \pm 0.8\end{array}$ & $\begin{array}{l}34.9 \pm 1.8 \mathrm{NS} \\
27.8 \pm 0.9 * *\end{array}$ & $\begin{array}{l}37.9 \pm 2 \\
10.0 \pm 0.6\end{array}$ \\
\hline
\end{tabular}

From Bolin, Pirola and Davis, (1969).

(a) 18 rats; (b) 17 rats ; ** $P<0.001$.

\section{Lipid digestion.}

Dietary lipids containing mainly triglycerides are hydrolyzed in the intestinal lumen by pancreatic lipase in the presence of bile salts and colipase. The latter, of pancreatic origin, is a lipase cofactor recently demonstrated by Maylie et al. (1973) and studied by several authors (Borgström and Erlanson, 1973 ; Borgström, 1977 ; Rietsch et al., 1977). The monoglycerides and fatty acids released are vehiculed by the bile micelles to the intestinal mucosa where they are absorbed. In the enterocyte they undergo enzymatic reesterification.

\section{1. - Pancreatic digestion.}

Pancreatic lipase adaptation to dietary lipid has been reported by Bucko and Kopec (1968) and confirmed by Deschodt-Lanckman ef al. (1971) in the rat (fig. 6). It has also been shown in the dog (Behrman and Kare, 1969), chicken (Wills and Hinners, 1968) and pig (Corring, 1975) (fig. 5). The specific lipase activity in pig pancreatic juice is 7 times higher when the daily amount of dietary triglyceride intake increases from 30 to $220 \mathrm{~g}$. It should be recalled that the adaptation of lipase was demonstrated much later than that of the other pancreatic enzymes. The type of 
liplds used in the different diets may have had a special effect; according to Deschodt-Lanckman et al. (1971), lipid containing unsaturated fatty acids stimulates lipase synthesis more than that containing saturated fatty acids. Another explanation is furnished by Gidez (1973) who believes that the relative amounts of dietary lipid, protein and carbohydrate may affect the degree of variation of lipolytic activity. The very high increases in specific lipase activity reported by Deschodt-Lanckman et al. (1971) could thus be partly due to a very high protein diet (38 p. 100) containing no carbohydrate. Finally, a third explanation, which may be considered as a variation of the preceding one, has also been advanced by Gidez (1973). It concerns the energy supplied to the animal in the form of carbohydrate or lipid. In other words, the relation between dietary carbohydrate and lipid, in terms of assimilable animal energy, would explain why variations in lipase activity are either inexistant or high. Snook (1971) showed that the rat pancreatic lipase level increased when lipid-rich butter diets supplied more than 55 p. 100 of the dietary calories in the form of lipid. According to Gidez (1973), this percentage was lower (about 43 to 50 p. 100) when cornoil was given. Here again, the type of dietary lipid seemed to be implicated in the observed differences.

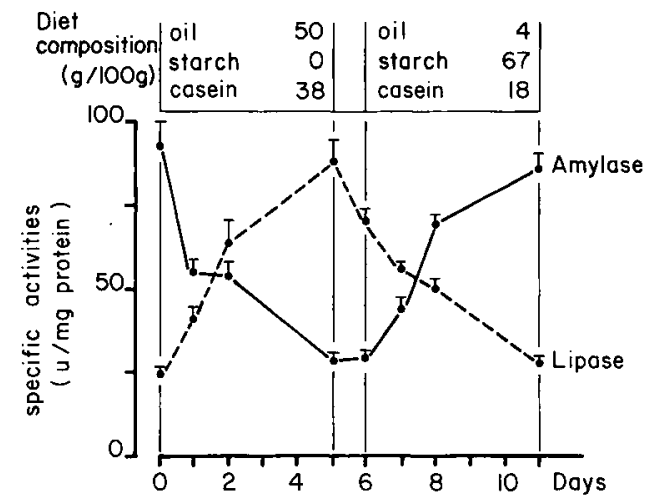

FIG. 6. - Short-ferm diefory adaptation of amylase and lipase. Adult rats adapted to a car bohydraterich diet (48 p. $100 \mathrm{w}: \mathrm{w}$ ) were fasted 1 day and then fed a 50 p. 100 cornoil diet for 5 days. After a short 24-hr fast, they were fed a 67 p. 100 starch diet. Groups of 6 or 12 rats were killed at different time intervals. Each point is the mean specific activity ( $\mu / \mathrm{mg}$ of protein) and the vertical bars are the SEM (Deschodt-Lanckman et al., 1971).

To my knowledge, only three studies have been done on colipase variation in response to a change in the amount of lipid intake ; two of these studies were carried out in the rat (Girard-Globa and Simond-Cote, 1977 ; Vandermeers-Piret ef al., 1977) and one in the pig (Mourot and Corring, 1979). The results are contradictory since according to Girard-Globa and Simond-Cote (1977), rat colipase adapts to dietary lipid, while Vandermeers-Piret ef al. (1977) concluded that there was no adaptation. Pig colipase (Mourot and Corring, 1979) adapted to the amount of lipid intake in animals eating the same quantities of two diets containg 5 and 25 p. 100 of peanut oil, respectively (table 6). Lipase and colipase do not seem to adapt parallellely to the lipid-rich diet : + 82.6 p. 100 for lipase and +33.7 p. 100 for colipase. 
TABLE 6

Effect of dietary lipid level on specific lipase

and colipose activities in the pancreatic tissue of pair-fed pigs.

\begin{tabular}{|c|c|c|c|}
\hline & Lot A ( $\left.{ }^{1}\right)$ & Lot B $\left({ }^{2}\right)$ & $\begin{array}{l}\text { Statistical } \\
\text { significance }\end{array}$ \\
\hline $\begin{array}{l}\text { Chymotrypsin } \\
\text { Amylase } \ldots . . \\
\text { Lipase ...... } \\
\text { Colipase .... }\end{array}$ & $\begin{array}{rlr}6.56 & \pm & 0.8 \\
1913 & \pm 432 \\
67.7 & \pm 6.9 \\
119.9 & \pm 15.4\end{array}$ & $\begin{array}{c}7.13 \pm 0.6 \\
3030 \pm 581 \\
370 \pm 10.2 \\
87.2 \pm 21.2\end{array}$ & $\begin{array}{c}\text { NS } \\
P<0.001 \\
P<0.001 \\
P<0.005\end{array}$ \\
\hline
\end{tabular}

From Mourot and Corring (1979).

(1) Diet containing 25 p. 100 lipid and 31.5 p. 100 starch.

( ${ }^{2}$ Diet containing 5 p. 100 lipid and 51.5 p. 100 starch.

\section{2. - Intestinal digestion.}

After infestinal hydrolysis, the released fatty acids and monoglycerides are absorbed mainly in the jejunum (Booth, Read and Jones, 1961). Rodgers and Bochenek (1970) showed that there was more lipid reesterifying enzyme activity in the proximal zones of the small intestine. According to Rodgers (1970) and Mc Manus and Isselbacher (1970), the process of intestinal reesterification responds to changes in the amounts of lipid substrate digested. This is evident in fed animals which showed increased total specific monoglyceride acyltransferase octivity as compared to the fasted ones (Rodgers, 1970). Similar results were obtained by Mc Manus and Isselbacher (1970) for acyl-CoA-synthetase. According to Singh ef al. (1972), the adaptive increase in monoglyceride transferase activity was accompanied by increased monoglyceride absorption.

\section{Physiological significance of digestive enzyme adaptation to the diet.}

From the above analysis, it is clear that any alteration in the amount of protein, carbohydrate or lipid intake causes an adjustment in the enzymes hydrolyzing those substances. For example, increasing starch intake causes pancreatic amylase activity to augment, which in turn induces an increase in the quantity of disaccharides released. It was seen that the latter increase stimulates disaccharidase enzyme activity; this is also true for protein and lipid digestion. The enzymes adapt to the diet within 2 to 3 days and this adaptation is stabilized after 5 to 7 days (Ben Abdeljlil and Desnuelle, 1964 ; Corring and Saucier, 1972 ; Corring, 1975). However, recent studies have shown that quantifatively changing a substrate has a very rapid effect on the corresponding enzyme activity. Pancreatic enzyme biosynthesis varied in the $30 \mathrm{~min}$ following a change in rat dief composition (Dunningan and Paradis, personal communication). In the pig, the specific amylase activity in the pancreatic juice augmented in the 2 hrs following increased starch intake (Simoes-Nunes and Corring, 1979). To explain why it takes a relatively long time for enzymatic adaptation to be established, Corring (1977) suggested that it depends on the adjustment of other digestive 
processes such as gastric emptying or intestinal motility. The presence of a stable amount of substrate in the intestinal lumen, leading to a new enzyme activity, would thus necessitate the previous adaptation of digestive motor processes. The stimulus of changing the diet composition would cause a very short-term digestive response which must be repeated (intake of several meals of the new diet) in order to establish a new enzyme activity. In studies on digestive enzyme adaptation to the diet, the values of enzyme activities are usually the daily means which do not show the immediate effects of intake. Moreover, the adaptation time may vary with the synthesis site, depending on the enzyme. Thus, variation of disaccharidase activity is closely related to the cell renewal rate of the intestinal epithelium (Rosensweig, Herman and Stifel, 1971).

The adaptive process having been described, omitting the mechanisms involved, the question of its physiological significance will now be discussed. What is the utility of such a process to the organism? In what cases does it permit the animal to adapt to the external and infernal conditions of its environment?

The answer to these questions is complicated by an enzyme excess in the digestive secretions, particularly pancreatic secretion. Several authors have shown that exocrine pancreatic enzyme equipment is sufficient for hydrolyzing a much higher quantity of substrates than is usually ingested. According to Gray (1971), man secretes 10 times the amount of amylase needed for digestion and has enough for starch digestion, even if the pancreas is deficient. Rats digesting carbohydrate rich diets have enough amylase in the intestinal contents for hydrolyzing 0.5 to $1.0 \mathrm{~g}$ of starch per minute (Snook, 1965). According to Snook (1974), adding pancreatin did not enhance the growth rate or protein digestion in rats fed casein or a mixture of wheat gluten and zein (table 7), even if their pancreatic protein store was reduced by 50 p. 100. In spite of the lack of experimental data, there is no reason why such an enzyme excess should not be found in other digestive secretions such as those of the stomach or intestine. It is therefore difficult to explain why digestive enzyme capacity increases when it is already sufficient for digesting large accumulated amounts of dietary substrate.

\section{TABLE 7}

Effect of pancreatin on apparent protein digestibility in pair-fed rats

\begin{tabular}{cc}
\hline Diet & $\begin{array}{c}\text { Apparent protein } \\
\text { digestibility }\end{array}$ \\
\hline Casein 10 p. $100 \ldots \ldots \ldots \ldots \ldots \ldots \ldots \ldots$ & $88.9 \pm 1.5$ \\
+1 p. 100 pancreatin $\ldots \ldots \ldots \ldots \ldots \ldots$ & $91.4 \pm 0.4$ \\
Gluten-zein ( ${ }^{1}$ ) $7.5-2.5$ p. $100 \ldots \ldots \ldots$ & $76.9 \pm 4.0$ \\
$\dashv 1$ p. 100 pancreatin. $\ldots \ldots \ldots \ldots \ldots$ & $83.2 \pm 1.5$ \\
\hline
\end{tabular}

From Snook (1974).

(1) The pancreatic proteolytic store was reduced by 50 p. 100.

A main point in digestive enzyme adaptation is the need for a minimum protein supply. During prolonged starvation (Rosensweig ef al., 1968 ; Siddons, 1972) or short-term dietary protein deficiency (Lê-Thanh Uyên, 1969 ; Nicholson, Mc Carthy 
and Kim, 1974 ; Corring and Saucier, 1972), all digestive enzyme activity is reduced. When the animal receives enough protein, the presence or absence of other dietary substrates affects the specific hydrolysis of the enzymes involved. Without entering into detail here concerning nutritional nitrogen and energy requirements (see reviews of Henry and Rérat, 1964 ; Rérat, 1974), it seems evident that the latter are largely covered by the experimental diets used in studies on enzyme adaptation. An example is casein, the protein usually used in studies in the rat. In a diet containing adequate amounts of carbohydrate and lipid, the casein level varies about 13 to 14 p. 100 in order to insure normal animal growth and development. Increasing this level from 17 to 85 p. 100 (Stifel ef al., 1968) or from 13 to 88 p. 100 (Scharrer, 1972) causes a significant augmentation of the enzymatic activities or of amino acid absorption, but has no effect on animal growth. On the contrary, when the protein supply is lower than the requirement, growth is affected (Nicholson, Mc Carthy and Kim, 1974). The latter authors showed that, intake being equal, the weight gain of rats fed a 55 p. 100 casein diet was significantly higher than that of rats fed a $10 \mathrm{p}$. 100 diet. If would thus seem that digestive enzyme adaptation to the diet has no utility in the physiological development of a normal, well fed animal. However, some authors believe that this utility would appear under some aspects. The hydrolytic rate of a substrate depends, among other things, on the enzyme concentration ; therefore the digestion of a substance could necessitate a higher enzyme concentration over a certain period. According to Shlygin (1977), if there was no adaptation, the digestive organ would produce higher amounts of all the enzymes; this would lead inevitably to undesirable alterations in the relationships of the digestive rates of different dietary components, and thus to changes in the absorption kinetics of various nutriments and their further metabolism. Snook (1974) believes that adaptation would be useful in decreasing enzyme activity and thus in reducing endogenous protein loss. She also proposed that the physiological utility of adaptation could not be evidenced simply because the digestion-absorption processes are not a limiting step in the use of dietary components. In other words, increasing the amount of substrate would cause an adjustment of digestive enzyme capacity but, for example, there would be no metabolic relay.

If the diet does not cover the nutritional needs of the animal, the process of digestive enzyme adaptation seems to be useful to the animal. Two situations may be distinguished : (i) the needs are not covered owing to dietary deficiency, and (ii) they are not covered because of an enzyme deficiency which leads to a lack of subsirates.

As regards dietary deficiency, the digestive secretions excrete large amounts of endogenous substances, such as proteins (Nasset, 1962 ; Rérat, Corring and Laplace, 1974) and phospholipids (Babushkina, 1961), into the gastrointestinal lumen. According to Shlygin (1977), the gastrointestinal tract responds to the lack of an essential dietary component by intensifying the production of a similar substance. The required level of these substances is thus maintained in the luminal contents and corrects the composition of the mixture absorbed. This theory agrees with Nasset's (1962) notion of internal intestinal homeostasis which is probably only valid during short-term fasting. Siddons (1972) reported during short-term protein restriction that the quantity and quality of endogenous protein were enough to insure normal disaccharidase activity in the chicken. The results of Lê-Thanh Uyên (1969) in the rat fitted with a pancreatic fistula are also interesting; that author showed that severe short-term 
reduction of the amount of dietary protein (1 p. 100) altered exocrine pancreatic secretion. However, a more moderate restriction ( 7 p. 100 protein) gave different results. During the first 2 weeks, the concentration and the total amounts of pancreatic enzymes decreased (fig. 7) ; after 2.5 months of prolonged protein malnutrition, the enzyme concentration regained its normal level and the amount of juice increased, being $11 / 2$ times higher than in the control animals (fig. 8). The total quantity of enzymes thus increased, possibly representing a protein substrate for the organism. According to Shlygin (1977), the adaptive capacity of the enzymes permits the organism to take up specific precursors in the blood and to actively distribute one or a group of given substances in the digestive tract lumen.

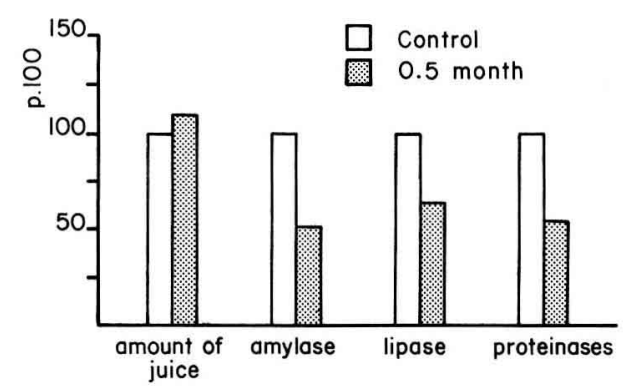

FIG. 7. - Decrease of enzymes secreted into the pancreatic juice of rats fed

a 7 p. 100 profein diet for 15 days (Le-Thanh Uyen, 1969).

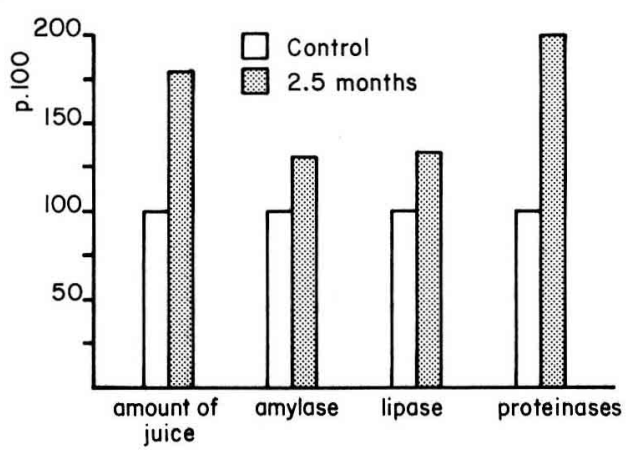

FIG. 8. - Increase of enzymes secreted into the pancreatic juice of rats fed a 7 p. 100 protein diet for $21 / 2$ months (Le-Thanh Uyen, 1969).

Studies on the absence of pancreatic hydrolysis have shown that enzyme deficiency significantly decreases, or even depletes, some substrates. The elimination of pancreatic enzyme hydrolysis in the intestinal lumen causes a reduction in digestive utilisation. This has been shown for pancreatic insufficiency (Säteri, 1975) and in experimental studies either after ligature of one or more pancreatic ducts (Shingleton ef al., 1955 ; Corring and Lebas, 1977 ; Corring and Bourdon, 1977) or after diversion of pancreatic secretion (Corring and Bourdon, 1976). In the rabbit and pig (Corring and Lebas, 
1977 ; Corring and Bourdon. 1977), ligating the pancreatic duct decreased apparent protein digestibility (mean 27 and 35.6 p. 100, respectively) and reduced apparent energy digestibility (mean 6 and 12 p. 100, respectively). However, the different digestibilities improved significantly with time (table 8) and animal growth remained

TABLE 8

Changes in the apparent digestibility coefficients of protein and energy in the rabbit (1) and the pig $\left({ }^{2}\right)$ after pancreatic duct ligature.

\begin{tabular}{|c|c|c|c|c|}
\hline & \multicolumn{2}{|c|}{ Protein (p. 100) } & \multicolumn{2}{|c|}{ Energy (p. 100) } \\
\hline & 1st period & 2nd period & 1st period & 2nd period \\
\hline $\begin{array}{r}\text { Rabbit SO } \ldots \ldots \ldots \ldots \ldots \\
\qquad \ldots \ldots \ldots \ldots \ldots\end{array}$ & $\begin{array}{l}71.7 \\
51.9\end{array}$ & $\begin{array}{l}70,5 \\
55.4\end{array}$ & $\begin{array}{l}64.7 \\
58.3\end{array}$ & $\begin{array}{l}66.7 \\
62.8\end{array}$ \\
\hline 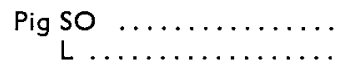 & $\begin{array}{l}76.0 \\
48.9\end{array}$ & $\begin{array}{l}81.6 \\
67.6\end{array}$ & $\begin{array}{l}78.3 \\
68.8\end{array}$ & $\begin{array}{l}81.8 \\
76.9\end{array}$ \\
\hline
\end{tabular}

(1) From Corring and Lebas (1977).

(2) From Corring and Bourdon (1977).

SO : sham-operated; L : pancreatic ligature.

1 st period : days 17 to 24 after ligature in the rabbit. days 15 to 24 after ligature in the pig.

2nd period : days 35 to 46 after ligature in the rabbit. days 78 to 87 after ligature in the pig.

positive, although lower than that of intact animals (fig. 9). This improvement is the result of the adaptive enzymatic increases reported by different authors and compensating for the elimination of pancreatic hydrolysis. Intestinal maltase (Rommel ef al., 1972) and saccharase (Arvanitakis and Olsen, 1974) increased significantly in the rat after exocrine pancreatic secretion was suppressed. Catala (1977) showed that rabbit intestinal microflora intensified its amylase production, and Corring, Moreau and Ducluzeau (1979) reported that the rat microflora was directly responsible for

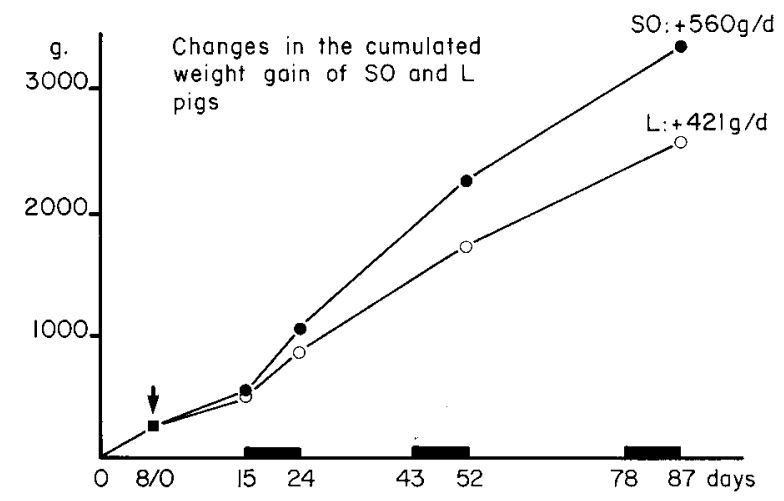

FIG. 9. - Cumulated weight gains of control pigs ( $\bullet$ and those with a pancreatic duct 'igature (0) Each point is the mean of 4 pigs \pm SEM (Corring and Bourdon, 1777). 
the utilisation of some of the non-hydrolyzed casein after pancreatic duct ligature. This digestive compensation illustrates the enzyme adaptive capacity of the organism, permitting it to compensate for pancreatic deficiency. To my knowledge, no experimental data have shown the same compensatory process in deficient gastric hydrolyis or in its suppression (Lundh, 1962 ; Hein, Silen and Harper, 1963 ; Gullo ef al., 1979). As for intestinal enzymes, it is known that severe, persistent lactase deficiency causes lactose intolerance (Bolin and Davis, 1972 ; Kretchmer, 1971). Sadikali (1971) has demonstrated that the glycyl-glycine absorption rate is reduced in patients suffering from glycyl-glycine peptidase deficiency.

\section{Conclusion.}

The present paper on the adaptation of digestive enzymes to the diet is not a complete review. Firstly, some enzymes, such as pancreatic phospholipases, have not been included and secondly, since there are so many examples of enzyme adaptation they cannot all be cited here. For instance, the exocrine pancreas augments its proteolytic enzyme biosynthesis when the animal ingests crude soya containing a trypsin inhibitor. It is also known that amino acids are released more slowly from crude soya protein. If this slow release is due to proteolysis inhibition, Snook (1974) believes that the increased proteolytic activity observed is advantageous.

The first part of this paper showed that the organism has a complete digestive equipment which can adapt to any alteration in the amount of substrate intake. In the second part of the paper, it was seen that this increase seemed to have no apparent advantage in the development of the normal, well fed animal. On the contrary, it would be useful when all the nutritional requirements are not covered by the diet. Dietary deficiency, particularly protein deficiency, if it is not too severe, is compensated for by digestive secretion supply; this compensation is only possible because of the adaptive capacity of the enzymes. In man, in which malnutrition or undernourishment are well known, it would seem that such cases would be rapidly and inevitably fatal, if there was no process of enzyme adaptation. Dietary deficiency could also be the result of a lack of substrate due to enzymatic deficiency; in some cases, enzyme adaptation limits its effects owing to digestive compensation. Although it cannot be considered as an endogenous digestive secretion, the intestinal microflora plays a crucial role which it is necessary to define, if the microflora is to be used as a digestive enzyme source in humans suffering from enzyme insufficiency or deficiency.

Journées Ingestion-Digestion-Absorption de l'Association française de Nutrition, Paris, 15-16 novembre 1979.

Résumé. D'une façon générale l'étape intestinale de la digestion est la plus importante dans le processus de dégradation enzymatique des composants alimentaires et l'examen de la litterature scientifique montre que plusieurs enzymes digestives s'adaptent à toute modification du régime ingéré par l'animal.

Dans une première partie nous avons rassemblé les données obtenues sur la capacité d'adaptation des enzymes pancréatiques et intestinales. Lorsqu'on considère successivement la digestion intestinale des protéines, des glucides et des lipides, il apparaît clairement 
qu'une variation des quantités de substrat ingéré entraine une adaptation de l'activité des enzymes qui hydrolysent ce substrat. Ainsi, quand la quantité d'amidon ingéré augmente, l'activité spécifique de l'amylase pancréatique est stimulée. De même l'augmentation de l'ingestion de disaccharides entraîne un accroissement de l'activité spécifique des disaccharidases et de la vitesse d'absorption de quelques produits d'hydrolyse tels que le fructose. Une modification de la quantité d'amidon ingéré conduit donc à une variation dans le même sens de l'activité de l'ensemble des enzymes impliquées dans l'hydrolyse des glucides alimentaires.

Dans une deuxième partie nous nous sommes interrogé sur la signification physiologique de l'adaptation des enzymes digestives en termes d'utilité pour l'animal. Deux sifuations sont envisagées : (i) les besoins nutritionnels sont couverts par l'alimentation ; (ii) ils ne le sont pas soit à la suite d'une déficience alimentaire, soit à la suite d'une déficience enzymatique. Lorsque les besoins nutritionnels, notamment ceux en azote, sont couverts par le régime l'utilité de l'adaptation n'est pas évidente. Cependant le rôle de cette dernière dans la vitesse d'hydrolyse des différents substrats peut être suggéré. Lorsque les besoins nutritionnels ne sont pas couverts, un certain nombre de données expérimentales montre que l'adaptation des enzymes digestives peut être avantageuse pour l'animal. Si la restriction alimentaire n'est pas trop sévère ce qui entraîne une diminution de la biosynthèse de l'ensemble des enzymes, les sécrétions digestives exportent un matériel azoté important dans la lumière gastro-intestinale. Ce matériel peut être un substrat qui remplace les composants essentiels manquant dans le régime. Enfin, une déficience enzymatique se traduisant par une diminution de substrat est identique à une déficience alimentaire.

Plusieurs études expérimentales ont montré que dans le cas de déficience pancréatique, la capacité d'adaptation enzymatique de l'organisme est à l'origine de l'établissement d'une compensation digestive.

\section{Références}

ADIBI S. A., MORSE E. L., 1971. Intestinal transport of dipeptides in man : Relative importance of hydrolysis and intact absorption. J. clin. Invest., 50, 2266-2275.

ARVANITAKIS C., OLSEN W. A., 1974. Intestinal mucosal disaccharidases in chronic pancreatitis. Dig. Dis., 19, 417-421.

BABUSHKINA L. M., 1961. On the mechanism underlying secretion of phospholipids and nucleic acids forming part of the intestinal juice. Vop. med. Khim., 7, 259-265.

BEHRMAN H. R., KARE M. R., 1969. Adaptation of canine panereatic enzymes to diet composition. J. Physiol., 205, 667-676.

BEN ABDELJLIL A., DESNUELLE P., 1964. Sur l'adaptation des enzymes exocrines du pancréas à la composition du régime. Biochim. biophys. Acta, 81, 136-149.

BLAIR D. G. R., YAKIMATS W., TUBA J., 1963. Rat intestinal sucrase : II. The effects of rat age and sex and of diet on sucrase activity. Can J. Biochem. 41, 917-928.

BLUM J. C., GAUTHIER A., GUILLAUMIN S., 1979. Variations des activités maltase et invertase dans l'intestin de poulet en fonction de l'âge et du régime alimentaire. Ann. Biol. anim. Bioch. Biophys., 19, 807-812.

BOLIN T. D., DAVIS A. E., 1972. Primary lactase deficiency : Genetic or acquired ? Gastroenterology, 62, 355-356.

BOLIN T. D., PIROLA R. C., DAVIS A. E., 1969. Adaptation of infestinal lactase in the rat. Gastroenferology, 57, 406-409.

BOOTH C. C., READ A. E., JONES E., 1961. Studies on the site of fat absorption. I. The sites of absorption of increasing doses of ${ }^{131}$-labelled triolein in the rat. Gut., 2, 23-31.

BORGSTRÖM B., 1977. The action of bile salts and other detergents on pancreatic lipase and the interaction with colipase. Biochim. biophys. Acto, 488, 381-391.

BORGSTRÖM B., ERLANSON C., 1973. Pancreatic lipase and colipase : Interactions and effects of bile salts and other detergents. Europ. J. Biochem., 37, 60-68.

BUCKO A., KOPEC Z., 1968. Adaptation of enzyme activity of the rat pancreas on altered food intake. Nutr. Diet., 10, 276-287. 
BURSTON D., ADDISON J. M., MATTHEWS D. M., 1972. Uptake of dipeptides containing basic and acidic aminoacids by rat small intestine in vitro. Clin. Sci. (Oxf.), 43, 823-837.

CAIN G. D., MOORE P. Jr., PATTERSON M., MCELVEEN M. A., 1969. The stimulation of lactase by feeding lactose. Scand. J. Gastroenterol, 4, 545-550.

CATALA J., 1977. Effets de la ligature du canal pancréatique chez les lapins soumis à un régime alimentaire traditionnel. Ann. Biol. anim. Bioch. Biophys., 17, 573-578.

CLARY J. J., MICHTELL G. E., LITTLE C. O., BRADLEY N. W., 1969. Pancreatic amylase activity from ruminants fed different rations. Can. J. Physiol. Pharmacol., 47, 161-164.

CORRING T., 1975. Adaptation de la sécrétion du pancréos exocrine au régime alimentoire chez le porc. Physiologie comparée, étude expérimentale ef mécanismes. Th. Doct. Etat Sci. Nat., Paris.

CORRING T., 1977. Possible role of hydrolysis products of the dietary components in the mechanisms of the exocrine pancreatic adaptation of the diet. WId. Rev. Nutr. Diet., 27, 132-144.

CORRING T., BOURDON D., 1976. Short dated influence of removal of the exocrine pancreatic secretion (enzymatic or total) upon the apparent digestibility of a diet in the pig. Nutr. Rep. int., 14, 621-627.

CORRING T., BOURDON D., 1977. Exclusion of pancreatic exocrine secretion from intestine in the pig : Existence of a digestive compensation. J. Nutr., 107, 1216-1221.

CORRING T., LEBAS F., 1977. Effets à court ef moyen terme de la ligature du canal pancréatique sur la digestibilité d'un aliment, chez le lapin en croissance et soumis à une alimentation restreinte. Ann. Biol. anim. Bioch. Biophys., 17, 299-307.

CORRING T., MOREAU C., DUCLUZEAU R., 1979. Comparative apparent digestibility of casein in holoxenic, axenic and clostridium bifermentans monoassociated rats. Am. J. clin. Butr., 32, $1231-1237$.

CORRING T., SAUCIER R., 1972. Sécrétion pancréatique sur porc fistulé. Adaptation à la teneur en protéines du régime. Ann. Biol. anim. Bioch. Biophys., 12, 223-241.

CUATRECASES P., LOCKWOOD D. H., CALDWELL J. R., 1965. Lactase deficiency in the adult : A common occurrence. Lancet, 1, 14-18.

CUENOT L., 1951. L'évolution biologique, Paris.

DEREN J. J., BROITMAN S. A., ZAMCHECK N., 1967. Effect of diet upon intestinal disaccharidases and disaccharide absorption. J. clin. Invest., 46, 186-195.

DESCHODT-LANCKMAN M., ROBBERECHT P., CAMUS J., CHRISTOPHE J., 1971. Short- term adaptation of pancreatic hydrolases to nutritional and physiological stimuli in adults rats. Biochimie, 53, 789-796.

DESNUELLE P., REBOUD J. P., BEN ABDELJILL A., 1962. Influence of the composition of the diet on the enzyme content of rat pancreas, 90-114. In REUCK A. V. S., CAMERON M. P. The exocrine pancreas. Normal and abnormal functions. Ciba Fund. Symp. London.

EICHHOLZ A., 1969. Fractions of the brush border. Fed. Proc., 28, 30-34.

FREEMAN H. J., KIM Y. S., 1978. Digestion and absorption of protein. Ann. Rev. Med., 29, 99-116. GIDEZ L. I., 1973. Effect of dietary fat on pancreatic lipase levels in the rat. J. Lipid Res., 14, 169-177.

GIRARD-GLOBA A., SIMOND-COTE E., 1977. Nutritional and circadian variations in lipase activity and colipase saturation in rat pancreas. Ann. Biol. Anim. Bioch. Biophys., 17, 539-542.

GORILL A. D. L., THOMAS J. W., 1967. Trypsin, chymotrypsin and total proteolytic activity of pancreas, pancreatic juice and intestinal contents from the bovine. Anal. Biochem., 19, 211-225.

GRAY G. M., 1971. Intestinal digestion and maldigestion of dietary carbohydrates. Ann. Rev. Med., 22, 391-404.

GRAY G. M., COOPER H. L., 1971. Protein Digestion and absorption. Gastroenterology, 61, 355-544.

GROSSMAN M. I., GREENGARD H., IVY A. C., 1943. The effect of dietary composition on pancreatic enzymes. Am. J. Physiol., 138, 676-682.

GULLO L., COSTA P. L., VENTRUCCI M., MATTIOLI S., VITI G., LABO G., 1979. Exocrine pancreatic function after total gastrectomy. Scand. J. Gastroenferol., 14, 401-407.

HEIN M. F., SILEN W., HARPER H. A., 1963. Mechanism of canine gastric hypersecretion after complete pancreatic ductal obstruction. Am. J. Physiol., 205, 89-93.

HEIZER W. D., KERLEY R. L., ISSELBACHER K. J., 1972. Intestinal peptide hydrolase differences between brush border and cytoplasmic enzymes. Biochim. biophys. Acta, 264, 450-461.

HENRY Y., RÉRAT A., 1964. Variations des taux énergétique et azoté dans l'alimentation du porc en croissance. Observations préliminaires. Ann. Biol. anim. Bioch. Biophys., 4, 263-271. 
HOWARD F., YUDKIN S., 1963. Effect of dietary change upon the amylase and trypsin activities of the rat pancreas. Brit. J. Nutr., 17, 281-295.

HULAN H. W., BIRD F. H., 1972. Effect of fat level in isonitrogenous diets on the composition of avian pancreatic juice. J. Nutr., 102, 459-468.

IMONDI A. R., BIRD F. H., 1967. Effect of dietary protein level on growth and proteolytic activity of the avian pancreas. J. Nuir., 91, 421-428.

KIM Y. S., BIRTWHISTLE W., KIM Y.W., 1972. Peptide hydrolases in the brush borders and soluble fractions of small intestinal mucosa of rat and man. J. clin. Invest., 51, 1419-1430.

KIM Y. S., MCCARTHY D. M., LANE W., FONG W., 1973. Alterations in the levels of peptide hydrolases and other enzymes in the brush border and cytosol fractions of rat small intestinal mucosa during starvation and refeeding. Biochim. biophys. Acto., 321, 262-273.

KNUDSEN K. B., WELSH J. D., KRONENBERG R. S., VANDERVEEN J. E., HEIDEBAUGH N. D., 1968. Effect of a nonlactose diet on human intestinal disaccharidase activity. Am. J. Digest. Dis., 13, 593-597.

KRETCHMER N., 1971. Memorial lecture. Lactose and lactase : A historical perspective. Gastroenterology, 61, 805-813.

LÊ-THANH UYÊN, 1969. Active adaptability of the pancreas to low-protein diet. Vop. Pitan., 28, 3943.

LUNDH G., 1962. The mechanism of postgastrectomy malabsorption. Gastroenterology, 42, 637-640.

MCMANUS J. P., ISSELBACHER K. J., 1970. Effect of fasting versus feeding on the rat small intestine. Morphological, biochemical and functional differences. Gastroenterology, 59, 214-221.

MAYLIE M. F., CHARLES M., ASTIER M., DESNUELLE P., 1973. On porcine pancreatic colipase. Biochem. Biophys. Res. Commun., 52, 291-297.

MILLER D., CRANE R. K., 1961. The digestive function of the epithelium of the small intestine. Il. Localization of disaccharide hydrolysis in the isolated brush border portion of intestinal epithelial cells. Biochim. biophys. Acta, 52, 281-298.

MOUROT J., CORRING T., 1979. Adaptation of the lipase-colipase system to dietary lipid content in pig pancreatic tissue. Ann. Biol. anim. Bioch. Biophys., 19, 119-124.

NASSET E. S., 1962. Amino acids in gut contents during digestion in the dog. J. Nutr., 76, 131-134.

NICHOLSON J. A., MC CARTHY D. M., KIM Y. S., 1974. The responses of rat intestinal brush border and cytosol peptide hydrolase activities to variation in dielary protein content. J. clin. Invest., 54, 890-898.

PAVLOV I. P., 1902. The work of the digestive glands. Transl. by W. H. Thompson. 1st ed. London, C. Griffin and Co.

RÉRAT A., 1974. Besoins azotés du porc. INRA ed., 3-32.

RÉRAT A., CORRING T., LAPLACE J. P., 1974. Protein digestion and absorption, 97-138. In COLE D. J. A. Protein metabolism and nutrition. E.A.A.P. 1st Symp., Nottingham, July 1974.

RIETSCH J., PATTUS F., DESNUELLE P., VERGER R., 1977. Further studies of mode of action of lipolytic enzymes. J. biol. Chem., 252, 4313-4318.

RODGERS J. B., 1970. Lipid absorption and lipid reesterifying enzyme activity in small bowel of the protein deficient rat. Am.. J. clin. Nutr., 23, 1331-1338.

RODGERS J. B., BOCHENEK W., 1970. Localization of lipid reesterifying enzymes of the rat small intestine. Effect of jejunal removal on ileal enzyme activities. Biochim. biophys. Acta, 202, 426435.

ROMMEL K., BÖHMER R., GOBERNA R., FUSSGÄNGER R., 1972. Influence of insulin and glybenclamide on the intestinal disaccharisades of subtotally pancreatectomized rats. Digestion, 6, 146-151.

ROSENSWEIG N. S., STIFEL F. B., HEMAN R. H., ZAKIM D., 1968. The dietary regulation of the glycolyłic enzymes. II. Adaptative changes in human jejunum. Biochim. biophys. Acta, 170, 228234.

ROSENSWEIG N. S., HERMAN R. H., 1969. Diet and disaccharidases. Am. J. clin. Nutr., 22, 99-102.

ROSENSWEIG N. S., HERMAN R. H., STIFEL F. B., 1971. Dietary regulation of small intestinal enzyme activity in man. Am. J. clin. Nutr., 24, 65-69.

SADIKALI F., 1971. Dipeptidase deficiency and malabsorption of glycylglycine in disease states. Gut, 12, 276-283.

SATERI H., 1975. Investigations of the exocrine pancreatic function in dogs suffering from chronic exocrine pancreatic insufficiency. Acta vet. scand. Supp. 53, 1-86. 
SCHARRER E., 1972. Adaptation of intestinal amino acid transport. Experientia, 28, 267.

SHINGLETON W. W., WELLS M. H., BAYLIN G. H., RUFFIN J. M., SAUNDERS A., DURHAM N. C., 1955. The use of radioactive labelled protein and fat in the evaluation of pancreatic disorders. Surgery, 33, 134-142.

SHLYGIN G. K., 1977. The physiology of intestinal digestion. Prog. Fd. Nutr. Sci, 2, 249-306.

SIDDONS R. C., 1972. Effect of diet on disaccharidase activity in the chick. Br. J. Nutr., 27, 343-352.

SIDDONS R. C., COATES M. E., 1972. The influence of the intestinal microflora on disaccharidase activities in the chick. Br. J. Nutr., 27, 101-112.

SIMOES-NUNES C., CORRING T., 1979. Pancreatic exocrine secretion in the pig following test meals of different composition and intra-duodenal loads of glucose and maltose. Horm. Metab. Res., 11, 346-351.

SINGH A., BALINT A., EDMONDS R. H., RODGERS J. B., 1972. Adaptative changes of the rat small intestine in response to a high fat diet. Biochim. biophys. Acta, 260, 708-715.

SNOOK J. T., 1965. Dietary regulation of pancreatic enzyme synthesis, secretion and inactivation in the rat. J. Nutr., 87, 297-305.

SNOOK J. T., 1971. Dietary regulation of pancreatic enzymes in the rat with emphasis on carbohydrate. Am. J. Physiol., 221, 1383-1387.

SNOOK J. T., 1974. Adaptative and non-adaptafive changes in digestive enzyme capacity influencing digestive function. Fed. Proc., 33, 88-93.

SNOOK J. T., MEYER J. H., 1964. Responses of digestive enzymes to dietary protein. J. Nutr., 82, 409414.

STIFEL F. B., ROSENSWEIG N. S., ZAKIM D., HERMAN R. H., 1968. Dietary regulation of glycolytic enzymes. 1. Adaptative changes in rat jejunum. Biochim. biophys. Acta, 170, 221-227.

STOROZUK P. G., 1968. Effect of protein products on gastric secretion in dogs. Vop. Pifan., 27, $50-55$.

VANDERMEERS-PIRET M. C., VANDERMEERS A., WIJNS W., RATHE J., CHRISTOPHE J., 1977. Lack of adaptation of pancreatic colipase in rats and mice. Am. J. Physiol. : Endocrinol. Mefab. Gastrointest. Physiol., 1, E 131-E 135.

VRANA A., FABRY P., KAZDOVA L., 1977. Diet-induced adaptation of intestinal fructose absorption in the rat. Physiol. Bohemoslov. 26, 225-234.

WILLS J. R., HINNERS S. W., 1968. Effect of diefary lipids upon the lipase, pancreatic cholesterol esterase, plasma triglyceride and total plasma lipid level in the chick. Poult. Sci., 47, 17321733 (Abstr.).

ZUBSTOV V. A., PODOROZHNAYA R. P., 1979. Effect of saccharose diet on the activity of enzymes and the carbohydrate metabolite content in the saliva of rats of various ages. Vop. Pitan., 2 , 47-49. 